\title{
Opinions of Turkish as a Foreign Language Learners on Academic Turkish
}

\author{
İsa Yılmaz \\ Recep Tayyip Erdoğan University, Turkey \\ E-mail: yilmzisa@gmail.com
}

Doi:10.7575/aiac.alls.v.8n.2p.180

URL: http://dx.doi.org/10.7575/aiac.alls.v.8n.2p.180
Received: 12/03/2017

Accepted: 27/04/2017

\begin{abstract}
The purpose of this study is to determine whether the language skills of the international students attending different Turkish language centers are sufficient to understand their departmental courses. The research was carried out through focus group interviews which are among the qualitative data collection techniques. For this purpose, 14 students studying at two different universities at different levels were selected on a voluntary basis. A semi-structured interview form was created with the help of three experts and was used to collect data for the study. The content analysis technique was used. Responses from 14 students were transcribed and analyzed both individually and entirely. It was detected that the level of Turkish taught at the Turkish language centers remained inadequate for the students to understand their departmental courses. The students had difficulties in understanding the concepts, terms, and sample texts related to their field. It is suggested that the students should be introduced with relevant academic concepts before starting their studies.
\end{abstract}

Keywords: teaching Turkish as a foreign language, academic Turkish, opinions of students

\section{Introduction}

The word academic refers to concepts that are related to education, especially at the college level (Longman, 2009; Türk Dil Kurumu, 2010). In some aspects, the academic language is distinguished from daily language. The academic language may include technical terms, the topics may be hard to understand, complex and intangible (Tompkins, 2009, p.14).

At the Workshop on Teaching Turkish as a Foreign Language 1 it was stated that the studies conducted on academic Turkish teaching practices were limited. In fact, the concept of teaching academic Turkish and its dimensions have not been defined clearly. One of the discussions related to this issue is that there is no agreement among the experts about the possible content of an academic Turkish course; should it be a general scientific research methods course or should it be created on field-specific contents? Despite the controversial discussions, a consensus emerged that there should be courses helping international students to learn the academic Turkish and to acquire them with general terminology related to their department. Further, interactions with Turkish as a second language learners revealed that the students also recognize the need for academic language skills. Starting from this point of view, the following definition should be made: Academic Turkish is the ability of expressing the concepts, terms or information which is specific to any field of scientific activities in Turkish.

Academic Turkish courses are needed to improve academic language skills of students. Despite its importance, in Turkey, there is a lack of research on international students' academic language skill problems. This might be due to the fact that the number of international students in Turkey has increased recently, and the issues started to emerge relatively late compared to western education systems.

There are different problems encountered by students who learn Turkish as a foreign language. Academic Turkish also has a special place among these problems. Students feel uneasy when they encounter a system at their department which is different than the system they are accustomed to in the Turkish teaching centres. Generally the students conclude that they did not comprehend Turkish at all. This study includes the students' opinions about the academic Turkish which is an important issue in the field of teaching Turkish as a foreign language and also some suggestions which were made in this regard. The data obtained from the focus group interviews made with the foreign students within the scope of this study is expected to give idea for those who will make a research on this issue.

In this study it was aimed to determine whether the Turkish knowledge of students learning Turkish in different language centers is sufficient to understand the lessons at their department. For this purpose, responds were sought for the following questions:

1 From result declaration of Measurement and Evaluation working group of Workshop of Turkish Education as a Foreign Language held between 2 to 5 April 2015 by the School of Foreign Languages of Akdeniz University. 
1. In which aspects the students who learn Turkish as a foreign language have difficulties when they start the education at their department?

2. Is the Turkish taught in Turkish education centre sufficient for academic environments?

3. What should the students who learn Turkish as a foreign language do to perform better in their courses?

4. How should the courses in Turkish as a second language programs be constructed that the students would feel more prepared for their department courses.

\section{Literature Review}

\subsection{Academic Turkish Applications}

Currently, there are only few studies published to identify the need of academic language support for international students in Turkey. Altun (2015) suggested that academic language courses should be offered in addition to Turkish as a second language courses and the academic language course curriculum should have the topics provided in Table 1. These topics are consistent with the academic English course package contents offered by Think Education (2015) which are; (a) academic reading and writing, (b) increasing the vocabulary, (c) text analysis, (d) writing reports and essays, (e) research skills and methods, (f) listening and note-taking skills,(g) language skills for academic materials research, (h) research project, (i) seminar or presentation title.

Table 1. Topics should be covered in academic Turkish curriculum according to Altun (2015)

$\begin{array}{ll}1 & \text { How to take notes in a course } \\ 2 & \text { Reading academic texts (e.g article, theses, books) and making inferences } \\ 4 & \text { Preparing homework, presentation } \\ 5 & \text { Preparing article, paper, theses (especially for graduate students) } \\ 6 & \text { Asking verbal question, responding to verbal questions } \\ 7 & \text { Answering comments, questions during written exam } \\ 8 & \text { Making an verbal defence in front of the thesis jury or thesis monitoring committee } \\ 9 & \text { Monitoring academic meetings such as conference, symposiums, taking notes, asking questions. }\end{array}$

Inal (2007) also identified the need of separate academic courses; he stated that students' English reading texts can be selected based on their anticipated study field and it will contribute to their adaptation process to the department. Separate sources should be prepared for the social sciences, health and physical sciences. There is a 133-page document available in the field conducted by Akbaba, Özkan and Uzun (2015) and, there are studies carried out in Altun's editorial (2015). In addition, Şen (2015) studied vocational language features of economics and administrative sciences courses taught in Turkish. The author concluded that vocational language, as it can be seen as a form of academic Turkish, should be taught separately than general language courses. In conclusion, studies conducted on this issue in our country are quite limited.

In order to enable the students to use Turkish in an academic environment, practices should be carried out to develop the speaking and writing skills of students within the scope of this course. Tok (2012) states that in academic writing the metaphorical and artistic discourse is absent and the basic and terminological meanings of the words are used. In addition, the students should do preparatory work for the courses so that they could easily understand the terminology which is specific for the given area. For this purpose, listening exercises including academic subject should be also available. For example this could be a lecture video or a conversation, interview, documentary or a news text made in relation with given field. As a result of all these activities, the students are expected to develop a skill which makes them able to distinguish the academic information from the non-academic knowledge, to distinguish an academic text that they read or heard from the other texts, to make inferences and to use the specific words in their native place. Inal (2007) stated that the purpose of reading instructions for academic purposes was to help the students to understand the textbooks and the written texts which they read at their department.

A related issue is the assessment and evaluation of a possible academic Turkish course. When making measurements in foreign language teaching, firstly, the aim should be well-defined then a variety of questions should be ensured according to skills which are to be measured. Later on feedbacks should be given to the students about all areas of the language skills within the evaluation studies carried out according to the measurement results (Y1lmaz, 2014, p.23). According to cognitive theory of the foreign language acquisition the learning of the students comes first. Although exams are prepared to detect that at which subjects the students are successful or at which subjects they failed, the main thing is to make the students taste the success (Ceyhan, 2007, p.100).

Instead of summative evaluation, formative forming and training oriented evaluation should be adopted for the measurement and evaluation in academic Turkish courses. The performance of the students should be considered in the courses. The participation of the students should be ensured in the reading and writing activities. At the end of the academic Turkish courses the students should prepare a presentation which include basic concepts specific to the field they are studying at. "In addition, in evaluation studies, the students should adopt motivating style and they should avoid judgmental and insulting statements in their evaluation studies" (Y1lmaz, 2014, p.23). 
Given that there is a paucity of information on the concept of academic Turkish and its possible applications, a brief literature review was conducted to investigate the concept of academic English for international students and related practises.

\subsection{Academic English Applications}

The academic Turkish practises are still new in Turkey, hence, examining the academic English courses may be important to have an opinion on how teach academic contents In the promotional programs of Indiana University's (2015) academic English courses, it was emphasized that the Academic English (English for Academic Purposes-EAP) program allows the students to practice directly what they learnt in this program also in the other courses. It is stated that students could get special attention from teachers since many of the EAP program were carried out in small class. It was stated that EAP courses were usually held in three or four hours a week and that they included interesting class and homework.

According to Hyland (2006) academic English was considered to be difficult for the students who had limited English skills. These students are not ready for specific language and learning assignments and they need preparation classes to learn general English thoroughly. "It was reported that those who attended EAP course were in better position compared to those who did not attend. They thought that both the English support and the academic English were necessary and useful during the process of academic cultivation." (Fox, Cheng, Berman, Song and Myles, 2006, p. 88).

\section{Method}

\subsection{Research Design}

Research was conducted through case studies from the qualitative research design. Case study is the in-depth description and analysis of a limited system (Merriam, 2013, p.40). According to Creswell (2007) case study is a qualitative approach in which the cases and case-based themes are examined in details by means of multiple data collection tools of limited one or more system. "Focus group interview is an interview on a specific topic made with a small group of people. Groups are generally formed with the participation of six to ten people who have similar experience history and the sessions last for one or two hours." (Patton, 2002, p.385). The creation of focus groups depends on the subject to be discussed. Similarly to the individual interviews, here it is also required to include people who are related to the issue through objective sampling into the research (Merriam, 2013, p.91-92). It is recommended that the size of the focus group should not be more than seven people since it may lead to complex problems. Therefore, a larger number of groups can be divided into smaller focus groups (Krueger, 1994). In light of these suggestions, this study was designed to have fourteen individuals and two different focus groups which are described next.

\subsection{Study group}

Target audience of the academic Turkish is students who are learning Turkish as a foreign language. The foreign students who will start undergraduate, graduate, postgraduate and doctoral education constitute this target audience. Students studying at Turkish language centres can take the pre- undergraduate education while the students who are learning Turkish at undergraduate level in Turcology centre in abroad can start directly at a master's degree. There are also students who want to pursue another field of doctoral education, outside the area where they completed their master's degree. Thus, academic Turkish courses is a helping and complementary education for foreign students at every level.

The study group consists of fourteen students visiting from five different countries who are registered at the preparatory, undergraduate, pre-license and graduate programs of the Ataturk University and Recep Tayyip Erdogan University within the 2014-2015 academic years. Information about the study group of the research is given in Table 2.

Table 2. The demographic characteristics of the study group

\begin{tabular}{llccc}
\hline $\begin{array}{l}\text { The student } \\
\text { code }\end{array}$ & \multicolumn{1}{c}{ Section } & Class & Gender & Country \\
\hline $\mathrm{S}_{1}$ & Medicine & 1 & Male & Yemen \\
$\mathrm{S}_{2}$ & Medicine & 1 & Male & Yemen \\
$\mathrm{S}_{3}$ & Dentistry & 1 & Female & Yemen \\
$\mathrm{S}_{4}$ & Islamic History and Arts & Post Graduate & Male & Yemen \\
$\mathrm{S}_{5}$ & Turkish Teaching & 4 & Male & Kirghizstan \\
$\mathrm{S}_{6}$ & Turkish Teaching & 4 & Male & Turkmenistan \\
$\mathrm{S}_{7}$ & Public administration & 4 & Male & Mongolia \\
$\mathrm{S}_{8}$ & Nursing & 3 & Female & Georgia \\
$\mathrm{S}_{9}$ & Nursing & 3 & Female & Georgia \\
$\mathrm{S}_{10}$ & Office management & 2 & Female & Georgia \\
$\mathrm{S}_{11}$ & Business management & 2 & Male & Georgia \\
$\mathrm{S}_{12}$ & Agricultural engineering & Preparatory & Male & Mongolia \\
$\mathrm{S}_{13}$ & Constructional & year & Male & Turkmenistan \\
$\mathrm{S}_{14}$ & engineering & 4 & Male & Turkmenistan \\
& Mathematics Teaching & 4 & & \\
\hline
\end{tabular}


10 of students in the study group were male while 4 of them were female. Focus group interviews were carried out with these students. In this study homogenous sampling was chosen among the purposeful sampling method for determining the students who will be interviewed. The aim here is to study some subgroups in depth by taking small and homogeneous sample. Focus group interviews are mostly performed on groups that are homogeneous. The aim here is to make group discussions on key issues which affect the members of the study group who come from similar structure and have similar experiences (Patton, 2014, p. 236).

\subsection{Collection and analysis of data}

Semi-structured interview form was used as qualitative data collection tool for data collection. "The semi-structured interview form combines both the fixed choice response and also the ability to go deep into the relevant area." (Büyüköztürk, Kılıç-Çakmak, Akgün, Karadeniz and Demirel, 2011, p.163) Before preparing the semi-structured interview form, the relevant field literature was examined and the opinions of the students who are learning Turkish as a foreign language and are studying at different departments were exchanged. As a result of these studies the interview questions were prepared about the subject of the research. Written questions were discussed with the help of three experts (instructors, research assistants, assistant professor) who were teaching Turkish in the related field and the draft of the interview form was created. Then, interviews were made with two of the foreign students by using the draft form. The parts where the students could not understand the questions or hesitated were revised again and then the final form was given. Questions in the final form can be seen in Table 3 through 8.

The three-hour audio recording which was taken during the interviews with students was transcribed by the researcher. The interviews which were transformed into text were subjected to content analysis. The transcripts were examined by an expert of the field and it was compared with data collected by the researchers. Several parts of the analysis and the comment differences were re-evaluated and the final codes were created.

At the beginning of the form which was used in the study there was a section where information was provided about the researcher, the aim of the research and about the departments, classes and countries of the students. The other part of the form is reserved for the interview questions. There were 6 open-ended questions in the student interview form. The $2^{\text {nd }}$ question on the form was supported by the probes. 2 The questions were related to the courses in Turkish teaching centre (TÖMER), problems encountered in the courses and solutions, opinions about the department where they are studying at and finally recommendations of the foreign students.

\section{Findings}

The findings related to the question whether the Turkish knowledge of the foreign students who were learning Turkish as a foreign language were sufficient to succeed in the lectures of their departments and to the recommendations they made for those who learn Turkish as a foreign language. The obtained findings are presented below in tables.

Table 3. Student's opinions about first course in the department

\begin{tabular}{lll}
\hline Students opinions & Students codes & f \\
\hline Thinking that the Turkish used in the lessons was difficult & $\mathrm{S}_{4,5,9,14}$ & 4 \\
Worrying too much in the first lesson & $\mathrm{S}_{2,3,8,10}$ & 4 \\
Cannot understand a large part of what was described in the course & $\mathrm{S}_{6.11}$ & $\mathrm{~S}_{13}$ \\
Too much uneasiness in the courses & $\mathrm{S}_{12}$ & 1 \\
Cannot understand anything in the courses & $\mathrm{S}_{7}$ & 1 \\
Can understand the words related to greeting & $\mathrm{S}_{1}$ & 1 \\
Feeling as it's the first time to come to Turkey & & 1 \\
\hline
\end{tabular}

The fact that the student coded as $\mathrm{S}_{3}$ stated that some of the teachers treated them badly when they had difficulty in understanding the lessons shows that the teaching members ignored the fact that these students were different from those whose mother language was Turkish.

Student 3: We were concerned. One of the teachers: Why did you come to this department? Other students have better Turkish...So, some teachers treated us badly.

Students who had difficulties in the first course were thinking about to leave their departments. They thought that the lessons were told very quickly. Also they did not get an answer when they asked their friends about the part they did not understand. Opinions of different students on this issue were given below:

Student 8: I said to myself when I enter the first course "when and how can I catch up them?" I understood some of the words, but there were some others which I could not understand. There were terms which I did not hear before.

2 In this study, TÖMER (Türkçe $\ddot{O}$ ğretim Merkezi) is used as the general name of the Turkish education center. It may be called differently by the other universities. 
Student 1: It was like the first time when I came to Turkey. The teacher was speaking and I was trying to understand but I couldn't. Teacher showed 60-70 slides in an hour, it was very difficult for us since we were not used to it. .

Student 10: The first lesson was very difficult for me. I thought I could not do it. I panicked.

Student 11: The first lessons were also very difficult for me, because I did not understand $80 \%$ of what the teacher was telling.

Student 12: Teacher was talking about anything and I did not understand. I asked the boy next to me but this time he did not understand me.

The student No 4 stated that the first lesson was very difficult and he also stated that his school mates from the lower classes had also difficulties in Turkish since they graduated without having a full knowledge in Arabic language in the high school. Student No 2 said that one of their friends left the school after the first week and returned to his own country. He said that he was thinking to do the same but he tried to be patient. Student No 6 mentioned the things he made to understand lessons instead of sharing his opinion about the first lesson. The student stated that at first, he could not understand $80 \%$ of the lesson but he noted the unknown words and he looked at them in the dictionary when he was at the home.

Table 4. Student opinions related to the language origin problems

\begin{tabular}{lll}
\hline Students opinions & Students codes & f \\
\hline Idioms and proverbs & $\mathrm{S}_{5}$ & 1 \\
English terms & $\mathrm{S}_{11}$ & 1 \\
Revolution history & $\mathrm{S}_{6.8}$ & 2 \\
Latin words & $\mathrm{S}_{8.9}$ & 2 \\
Verbal lessons & $\mathrm{S}_{5,7,12}$ & 1 \\
Pronunciation & $\mathrm{S}_{10}$ & 1 \\
Translations made from Turkish into other languages & $\mathrm{S}_{13.14}$ & 2 \\
Turkish concepts & $\mathrm{S}_{1,2,3}$ & 3 \\
Spelling and Grammar & $\mathrm{S}_{4}$ & 1 \\
\hline
\end{tabular}

When looking at the opinions of the students in Table 4 about the most difficult lessons it is noticeable that the lessons called the History of Revolution was considered to be the most difficult. Opinions regarding this lesson were the followings:

Student 6: The lesson called the History of Revolution was one of the lessons which I was unable to understand. There is some words and terms related to history and we cannot understand them.

Student 8: I was crying during the course of History of Revolution.

A student studying at the department of public administration stated that he did not have many difficulties with the numerical courses but in the verbal courses it was particularly difficult to understand the words with Arabic origin. The opinion of this student is the followings:

Student 7: I didn't have any difficulties in accounting lesson because its numeric but I had difficulty in verbal lessons such as Turkey's Social Structure, Social Sciences, and Human Resources. For example, it is still difficult to understand the difference between the words of a "assume" "prerogative" and "execution".

The student No 4 stated that he had concerns about making long sentences such as in Arabic and about writing. Another student studying at the department of Turkish Teaching said that he had difficulty in idioms and in the literature lessons at first. The student No 10, who was from Georgia, mentioned that he had difficulty in the phonation of thick-thin letters. The fact that there is no distinction between the thick and thin and big and small letters in the Georgian language was generally a problem mentioned by most of the students participating in the research. The opinions of some students were given below regarding the most common complaints about courses:

Student 4: Spelling and grammar is not enough. I'm trying to establish a long sentence, but I have concerns about writing.

Student 5: I had trouble with idiom generally, proverbs sometimes... New Turkish Literature, Ottoman Turkish, Divan Literature. I got the lowest points from these courses.

Student 10: I cannot get the letters in the correct way, the teacher cannot understand me. The most difficult is thick-thin letters... 
Table 5. Student opinions on whether the Turkish taught in TÖMER was sufficient to understand the lessons at the department

\begin{tabular}{lll}
\hline Students opinions & Students codes & f \\
\hline Enough & $\mathrm{S}_{14}$ & 1 \\
Not enough. & $\mathrm{S}_{1,2,3,4,5,6,7,8,9,10,11,12,13}$ & 13 \\
\hline
\end{tabular}

In Table 5, 13 of the 14 students who participated in the study stated that the Turkish they learned at the Turkish education centre was not enough to understand the lessons. The students studying at two different universities and at the departments of these universities shared the opinion that the Turkish courses they had attended before starting undergraduate and graduate programs were not sufficient. One of the students stated that the Turkish learnt at TÖMER was only sufficient in the everyday life. The opinion of this student was the following:

Student 1: It is not enough, because we have learned daily life Turkish. We did not learn scientific Turkish. We didn't know anything about biochemistry, biology, and biophysics.

Students studying medicine and nursing mentioned that they had not got any knowledge about the courses such as biochemistry, biophysics, and biology. The noteworthy thing here is the fact that these students had difficulties to find the Turkish correspondence of the concepts related to the course in their own faculty which means that they did not learn these lessons very well in their own countries. At the end of interview the students claims that in fact, their biggest problem was that the curriculum of the courses such as physics, chemistry and biology was different and insufficient in their countries. Students' opinions related to these are as follows:

Student 2: I think it was not enough (...) we did not even learn the chemical elements. We did not even learn the names of substances. lithium, nitrogen, zinc in the periodic table...

Student 8: I could not understand some of the words. I had difficulties in medical terms and Latin words.

A student stated that while they answered the questions in the exam, they wrote exactly what they memorized because they could not make comments but the Turkish students could. The student who was studying dentistry arrived with a copy of presentations made on the lessons to the interview. He said the following by showing the notes "Teacher, the Turks read them once in Turkish; but we must translate them before we can memorize". The student's statement during interview is as follows:

Student 3: It is not enough. For example, we were memorising everything. The teacher asks question, but we cannot answer, we are writing exactly what we memorized from the notes. However, the Turkish students write what they understood. But we want to write similarly.

A student mentioned that they had the same lessons with the Turkish students. Actually he should have known that special courses cannot be held for each student. The point that the student wanted to emphasize was that these students are unable to understand everything which was told by the teacher in the same way as the other students. The student's opinion related to these as follows:

Student 4: ...but we are attending the lesson as Turkish students in university. The same lecture is given to us as to them.

During the interview the students have expressed their opinions about orientation training. On the day when the foreign students first started their education at the campus they found the lessons that they did not encounter in the Turkish language centres and the operation of the university was the most challenging. In fact, in Turkish language teaching centre does not seem unfamiliar for the students. The problem starts when they enter the faculty. A student who was not informed about his department stated to that he had problems because of his poor Turkish:

Student 7: So, I say the Turkish that we learnt in TÖMER was useful but it was insufficient. I lost a whole year because of my poor Turkish. For example I thought that I was at the department of public administration in other words the department of finance. I thought it for a month or two. I thought that finance was public administration. I went, looked and it was public administration. It also happened because of my lack of Turkish. I misunderstood the word public administration as finances.

Coexistence of a large number of students who come from the same country or speak the same language brings along also some problems during the education process. During the period when the research was carried out, in a class where there were more Arab students, these students were asked what they were doing in the evening when they went home. Students told that they gathered within the room of the Arab students and that they were speaking Arabic. A similar situation was expressed during the interview:

Student 12: It was not enough, because, many people were coming from the same country when we were studying in TÖMER. For example, there were ten Mongols, and an Albanian in a class. We were talking Mongolian among ourselves, and the teacher began to learn Mongolian when he could not understand us.

Only one of the 14 students who were interviewed stated that he was satisfied with the Turkish he learnt in TÖMER. When the other students expressed the followings "We did not learn concepts and terms related to our department", this student approaches the event from a different point of view. 
Student 14: TÖMER should not be blamed. I was quite satisfied with it. Teachers do not need to know the terms used at your department. They cannot be competent about it. Department of your friends is certain, so you must prepare yourself accordingly.

Table 6. Students opinions about how to make the lessons more understandable

\begin{tabular}{lll}
\hline Students opinions & Students codes & f \\
\hline Asking for help from the friend & $\mathrm{S}_{1,3,6,8,9,10,11,12,14}$ & 9 \\
Asking for help from the teacher & $\mathrm{S}_{8,14}$ & 2 \\
Internet & $\mathrm{S}_{2,3,4,11}$ & 4 \\
Reading book & $\mathrm{S}_{4,8,9,10,11,14}$ & 6 \\
Using dictionary & $\mathrm{S}_{6,8,10,12,14}$ & 5 \\
Translation & $\mathrm{S}_{1,9,10,14}$ \\
Making friend with Turkish people & $\mathrm{S}_{5,11}$ & 4 \\
Finding the subjects of the lessons in English from & $\mathrm{S}_{2}$ & 2 \\
Wikipedia & & 1 \\
\hline
\end{tabular}

As it is seen in Table 6, the students stated that they asked for help mostly from their friends in order to understand the courses easier in their departments. It was followed by "reading" and "using the dictionary". Only one of the students stated that he was using Wikipedia for the English explanation of the subject that he could not understand. The related statements of the students were the followings:

Student 10: I study the subjects that I do not understand with a Turkish friend. I was reading story books.

Student 2: I use the Internet or Wikipedia to understand the subject.

It was observed that students were searching on the internet the meaning of words that they could not understand or the subjects that they could not understand. The noteworthy thing here is that the students studying especially at the medical faculty received negative answer when they wanted help from their friends. Student No 1: "We tried to understand the lessons by translating. We talked with some friends, but they did not help us. Because everybody was busy with their own troubles" In addition, student No 2 stated that he did not ask any help from his Turkish friends: I never asked my Turkish friends. Even if I ask I cannot understand their Turkish. They are telling, telling but I cannot understand them. The student No 3 used similar expressions: When we want help from the Turks some of them can tell while some of them cannot. We are working from morning till evening, but we are getting a bad mark.

"Friendship with the Turkish" mentioned by students also emerged as an important factor in learning Turkish quickly. The following student opinions confirm this:

Student 5: Foreign students were not so common when I first came. So, I was just spending time with Turkish friends. I developed my Turkish by speaking with them.

It was expressed earlier within the student's opinion that for the students it was very important to get information about the department, process of department and lessons. The following student statement is noteworthy because it shows the importance of informing the foreign students about the lessons. This student expressed the followings during the interview:

Student 9: We have translated even preface in anatomy book. We thought that it will be on the test.

Table7. The student opinions on how should be the Turkish lessons in TÖMER should be in order to make the lessons at the department more understandable?

\begin{tabular}{lll}
\hline Students opinions & Students codes & f \\
\hline Including academic subjects & $\mathrm{S}_{14}$ & 1 \\
Students attending the same department should be in the same & $\mathrm{S}_{5}$ & 1 \\
class & & \\
Making plenty of listening practices & $\mathrm{S}_{13}$ & 1 \\
Making guidance for department & $\mathrm{S}_{6}$ & 1 \\
Reading texts related to the department & $\mathrm{S}_{4.9}$ & 2 \\
Teaching terms and concept related to the department & $\mathrm{S}_{1,7,8,10}$ & 4 \\
Reading many books & $\mathrm{S}_{3.8}$ & 2 \\
Allowing only Turkish during the lessons & $\mathrm{S}_{12}$ & 1 \\
Making of speaking practice & $\mathrm{S}_{3,4,1}$ & 3 \\
Teaching the high school subjects & $\mathrm{S}_{1.2}$ \\
Making the students more active, making presentations & $\mathrm{S}_{14}$ & 2 \\
\hline
\end{tabular}


The issue related to physics, chemistry and biology course which was mentioned before is also seen in Table 7 . A student advised to the foreigners who learn Turkish that they should get the textbooks given the in high schools and they should study those books. Student opinions in this regard are the followings:

Student 1: Firstly, the Turkish knowledge needs to be developed, and the subjects taught in high schools should be learnt. It is important to know to the Turkish of terms and concepts.

Student 2: I think, students studying in TÖMER should finish C1 (Pre-advanced). Then, they should learn the final year subjects of high school.

In the research, most of students complained about not knowing the terms and concepts related to their department. Some of them mentioned that preparative texts should be read about their department and a student attending post graduate education mentioned that they needed to conduct more academic studies. Students' opinions related to these are given below:

Student 10: I would not have difficulty if we learnt the terms and concepts about the department.

Student 4: (...) the education received in TÖMER is different from the education of the department. For example, the articles and text about medicine should be read by the groups that will study medicine.

Student 14: It should be made more presentations in writing and speaking courses, because writing and presentation is always needed in the academic life... academic subjects for example reviewing articles and learning academic writing guide should be also discussed.

Student 9: Once in a week there should be such a lesson. Then it won't be so difficult at the beginning of the university.

The opinion about orientation study that was mentioned before is also encountered here. Students mentioned that they should be informed about their department before they start their studies. They stated that because of misunderstandings they lost a year moreover, they were forced to study in department that they did not want. Student opinion about orientation study is the following:

Student 6: Teachers there should give advice about the department. They should direct us like "you'd better do it, you'd better do that".

One of the students, who were interviewed, emphasized the importance of practicing in order to make the understanding easier and made the following suggestion:

Student 11: Students should go out once a week, and they should try to establish communication with the people around.

Table 8. Opinions about recommendations given to the students learning Turkish in order to be successful

\begin{tabular}{|c|c|c|}
\hline Students opinions & Students codes & $\mathbf{f}$ \\
\hline They should not speak in their own language. & $\mathrm{S}_{1,3,12}$ & 3 \\
\hline They should study very hard. & $\mathrm{S}_{2,10,14}$ & 3 \\
\hline They should not be embarrassed when they make mistake. & $\mathrm{S}_{4.10}$ & 2 \\
\hline They should read books. & $\mathrm{S}_{6,8,9,10,11,13}$ & 6 \\
\hline They should study the high school books. & $\mathrm{S}_{2}$ & 1 \\
\hline They should listen to music. & $\mathrm{S}_{8.9}$ & 2 \\
\hline $\begin{array}{l}\text { They should make friendship with Turks. They should } \\
\text { practice Turkish. }\end{array}$ & $\mathrm{S}_{1,3,4,5,9,11}$ & 6 \\
\hline They should watch series and cartons & $\mathrm{S}_{11.13}$ & 2 \\
\hline They should practice in writing. & $\mathrm{S}_{3.9}$ & 2 \\
\hline
\end{tabular}

Table 8 includes the recommendations given by the student in order to help the newcomers to become more successful in learning Turkish. "Reading books and establishing friendship and practicing with Turks" were the most common among the recommendations. Some student opinions in this regards are the followings:

Student 5: For example, Mongol friends should not speak Mongolian among themselves. So, for the quick learning, we should not speak our own language. In fact we should spend time with Turkish people in first year...

Student 6: They must read children's book, must read more it... Because, you can encounter with a word that you didn't counter and you are looking to the dictionary, it is the easiest way to learn, I think that they must more read books. Simple children's books...

Student 11: They should read books; they should watch TV, series, cartoons. They should read the book loudly. They should talk to people by going the bazaar.

There are also the followings among the recommendations "working hard, not to be ashamed of making mistakes, listening to music, watching series and cartoon, making the writing studies and studying the high school textbook". 
Another important issue is that the students should not speak their own language at school or at home. Student opinions in this relation are the followings:

Student 12: I think...the biggest problem was the following. Many people from the same country was included within the same class. This was the biggest problem, because they were speaking their own languages among themselves and they did not care too much about the Turkish language.

\section{Conclusion}

Many students who learn Turkish as a foreign language stated that they had difficulties when they started the lessons at their department. Students, who said that the Turkish they learnt was more beneficial in everyday life, stated that they had difficulties in understanding the subjects of the lesson and the specific terms. However, as it stated earlier, there is a paucity of research on the international students' sufficiency of academic Turkish.

It was observed that the majority of the interviewed students were nervous and had difficulties at the first course. It was observed that the students studying at the Faculty of Medicine and Dentistry had difficulties with the Latin word with the concept and terms and at the field courses. Sallabaş (2012) mentions that it is difficult to find Turkish text in studies conducted for professional Turkish learners. In addition, the lesson called the History of Turkish Revolution is also one of the lessons that challenge the students in understanding. Yahşi Cevher and Güngör (2015) stated in their research related academic Turkish that in undergraduate education foreign students are having difficulty in understanding the concepts and terms during the courses.

It was concluded that the level of Turkish taught in TÖMER was not enough to understand the lessons at the department. The students stated that they had difficulty in terms and concepts which are specific for the field they are studying. In addition, the presence of more students from the same country in the same class was seen as a factor that makes it difficult to learn the Turkish language. The students generally told that they learned daily life Turkish. The faculty members who were interviewed within the scope of Tok (2012)'s research stated that most of the students coming from Turkish education centre were inadequate for receiving Turkish education and they needed academic writings.

It was observed that students often got help from Turkish friends in order to understand lessons easier. In addition, it was concluded that they read book, used dictionary, made translations, and search for the topics on the Internet. In the study of Okatan (2012) it was also detected that the foreign students learnt faster and easier Turkish with the help of the guide students.

Boylu and Başar (2016) stated that language proficiency of the students with certificate were different from each other, and this caused problems in academic Turkish and the majority of the universities opened courses in this regard.

It was concluded that terms and concepts related to the faculties should be taught at the Turkish course of TÖMER in order to make the lessons more understandable. In addition, it was also stated that academic texts related to the department should be read and also more talking practices should be included within the Turkish courses. It is necessary to make the students more active during the lessons and not to allow them to speak their own languages.

It was observed that the participant recommended reading books and developing friendship with Turkish people for those who learn Turkish as a foreign language. Sallabaş (2012) stated that the students reading books had better notes compared to the students who were not reading. Besides, the following suggestions were done; do not speak their own language, study hard, do not hesitate to make mistakes, listen to Turkish songs, watch Turkish films, and do writing exercises. Okatan (2012) detected that some of the foreign students studying at the Police Academy as a guest avoided talking to Turkish school mates.

\section{Suggestion}

Orientation seminars can be provided for the students who learn Turkish as a foreign language when they begin their studies at the department. Motivating exercises can be made for the students because the Turkish they learnt in TÖMER is not enough to understand the whole lesson firstly.

Considering the difficulties that the students have in the lessons, academic texts for different disciplines can be processed after B2 level in the Turkish courses.

Academic Turkish courses should not be different or separate from other classes in the Turkish education centre but they should be reinforcing and supportive and should help the students to reinforce the knowledge they learned before and to prepare them for the departments they will study at.

The distribution of the students from the same country or the distribution of those speaking the same language should be considered in the classes. It should be provided that the students only speak Turkish as common languages.

Considering students mostly receive assistance from their Turkish mates to understand lessons easier, arrangements encouraging peer counseling in the class room can be done. Classified dictionaries for concepts and terms are required due to the fact that dictionaries are often used to understand the concept of terms especially in subjects such as social sciences, science and health studies.

Students should be encouraged to read books and it should be followed. Exercises developing the monitoring and listening skills of the students should be frequently used. The students should be ensured to speak Turkish during the lessons. The students should be encouraged to speak Turkish also at school, at their living shelter, and among friends. 


\section{References}

Akbaba, M., Özkan, T. and Uzun, H. (2015). Akademik Türkçe. (Unpublished undergraduate course notes). School of Foreign Languages of Akdeniz University, Antalya.

Altun, M. (Ed.). (2015). Akademik Türkçe Metinler-Alıştırmalar. Sakarya Üniversitesi TÖMER, Sakarya.

Boylu, E. \& Başar, U. (2016). Türkçe öğretim merkezlerininin güncel durumu ve standartlaştırılması üzerine. The Journal of Academic Social Science, Prof. Dr. İbrahim Kavaz Özel Sayısl, 4, 24, p. 309-324.

Büyüköztürk, Ş. Kılıç-Çakmak, E., Akgün, Ö. E., Karadeniz, Ş. \& Demirel, F. (2011). Bilimsel araştırma yöntemleri. Ankara: Pegem A Akademi.

Ceyhan, E. (2007). Yabancı dil öğretimi teknolojisi. İstanbul: Morpa Kültür Yayınları.

Creswell, J.W. (2007). Qualitative inquiry and research design: Choosing among five approaches (second edition). London: Sage Publications.

Fox, J., Cheng, L., Berman, R., Song X. and Myles, J. (2006). Costs and benefits: English for academic purposes instruction in Canadian Universities, Retrieved from http://carleton.ca/slals/wp-content/uploads/cpals-2006-Fox-etal.pdf.

Hyland, K. (2006). English for academic purposes: an advanced resource book. Taylor and Francis Group.

İnal, B. (2007). Akademik amaçlı okuma izlencesi oluşturmadaki temel kriterler. Journal of Arts and Sciences, 7, p. 4959.

Indiana University (2015). English for academic purposes. Retrieved from http://liberalarts.iupui.edu/english/uploads/docs/EAP.pdf.

Krueger, R.A. (1994) Focus groups: A practical guide for applied research. Thousand Oaks, CA: Sage.

Longman. (2009). Dictionary of contemporary English. China: Pearson Education Limited.

Merriam, S. B. (2013). Nitel araştırma, desen ve uygulama için bir rehber. (S. Turan, Çev. Ed.). Ankara: Nobel Yayın Dağıtım. (The original work was published in 1988.)

Okatan, H. İ. (2012). Polis Akademisi Güvenlik Bilimleri Fakültesinde okuyan yabancı uyruklu öğrencilerin Türkçe öğrenme sorunları. Polis Bilimleri Dergisi, 14, 4. p. 79-112.

Patton, M. Q. (2002). Qualitative research and evaluation methods. (3rd ed.). California: Sage Publication.

Patton, M. Q. (2014). Nitel araştırma ve değerlendirme yöntemleri. (M. Bütün and S. B. Demir, Trans. Ed.). Ankara: Pegem A Akademi. (The original work was published in 1980.)

Sallabaş, M. E. (2012). Türkçeyi yabancı dil olarak öğrenenlerin konuşma kaygılarının değerlendirilmesi. Turkish Studies,7(3), p. 2199-2218.

Şen, E. (2015). Ikktisadi ve idari bilimler Türkçesinin incelenmesi ve yabancı dil olarak Türkçe öğretiminde kullanımı. (Published doctoral dissertation). Dokuz Eylül University, İzmir.

Think Education (2015). English for academic purposes. Retrieved from http://www.think.edu.au/images/pdfs/EnglishLanguageCourses.pdf.

Tok, M. (2012). Türkçenin yabancı dil olarak öğretiminde akademik yazma becerilerinin geliştirilmesine yönelik uygulamalı bir çalışma (Unpublished doctoral dissertation), Çanakkale Onsekiz Mart University, Çanakkale.

Tompkins, G. E. (2009). Language arts. New Jersey: Pearson.

Türk Dil Kurumu. (2010). Türkçe sözlük. Ankara: Türk Dil Kurumu Yayınları.

Yahşi Cevher, Ö. \& Güngör, C. (2015). Applied study on importance of academic Turkish in Turkish language teaching as a foreign language on the base of Sakarya University Turkish teaching application and research center. International Journal of Languages' Education and Teaching,UDES 2015, p. 2267-2274.

Yılmaz, İ. (2014). Yabancı dil olarak Türkçe öğretiminde tamamlayıcı ölçme ve değerlendirme yöntemlerinin deyim ögretiminde kullanılmasına yönelik bir inceleme (Unpublished doctoral dissertation). Atatürk University, Erzurum. 